\title{
Intermittent drainage in paddy soil: ecosystem carbon budget and global warming potential
}

\author{
Md. Mozammel Haque ${ }^{1,2} \cdot$ Jatish Chandra Biswas $^{2} \cdot$ Sang Yoon Kim ${ }^{1} \cdot$ \\ Pil Joo Kim ${ }^{1,3}$
}

Received: 31 March 2016/Revised: 1 October 2016/ Accepted: 13 October 2016/Published online: 27 October 2016

(C) The Author(s) 2016. This article is published with open access at Springerlink.com

\begin{abstract}
Intermittent drainage of rice fields alters soil redox potential and contributes to the reduction of $\mathrm{CH}_{4}$ emission and thus may reduce net global warming potential (GWP) during rice cultivation. Incorporation of green biomass helps maintaining soil organic matter, but may increase $\mathrm{CH}_{4}$ emission. We investigated net ecosystem carbon budget (NECB) and net GWP under two water management regimes-continuous flooding and intermittent drainage-having four biomass incorporation levels $\left(0,3,6\right.$ and $\left.12 \mathrm{Mg} \mathrm{ha}^{-1}\right)$. Water management and biomass incorporation level demonstrated significant $(P<0.05)$ interaction effect on the NECB and GWP. Intermittent drainage decreased the NECB by ca. 6-46\% than continuous flooding under same rates of cover crop biomass (CCB) incorporation. Moreover, intermittent drainage reduced seasonal $\mathrm{CH}_{4}-\mathrm{C}$ fluxes by ca. $54-58 \%$ and net GWP by $35-58 \%$ compared to continuous flooding. There was also no significant reduction in rice yield because of intermittent drainage under similar CCB. This implies that incorporation of $3 \mathrm{Mg} \mathrm{ha}^{-1} \mathrm{CCB}$ and intermittent drainage could be a good option for reducing net GWP and higher grain yield.
\end{abstract}

Md. Mozammel Haque

mhaquesoil@yahoo.com

$\bowtie$ Pil Joo Kim

pjkim@gnu.ac.kr

1 Division of Applied Life Science (BK 21 Program), Gyeongsang National University, Jinju 660-701, South Korea

2 Soil Science Division, Bangladesh Rice Research Institute, Gazipur 1701, Bangladesh

3 Institute of Agriculture and Life Sciences, Gyeongsang National University, Jinju 660-701, South Korea
Keywords Net ecosystem carbon budget - Global warming potential - Water management

\section{Introduction}

Wetland rice culture has been identified as an important source of $\mathrm{CH}_{4}, \mathrm{CO}_{2}$, and $\mathrm{N}_{2} \mathrm{O}$ emissions (Haris et al. 1985; Bouwman 1990; Solomon et al. 2007; Lee 2010). These gases are responsible for global warming by 26,60 and $14 \%$, respectively (Neue and Roger 1993; Rodhe 1990; IPCC 2007). Greenhouse gas (GHG) emissions mainly take place from decomposing organic materials and microbial transformations of nitrogen $(\mathrm{N})$ in soils under reduced conditions (Takai 1961; Garcia et al. 2000; Janzen 2004; Oenema et al. 2005). Moreover, addition of organic materials can promote GHG emission by providing readily available carbon (C) and substrates for nitrifying microorganisms (Neue et al. 1997; Lee 2010; Hadi et al. 2010; Kim et al. 2013; Haque et al. $2013,2015 a$, b). So, it is likely that improved crop production strategies could reduce GHG emission from rice fields.

Mitigation of $\mathrm{CH}_{4}$ emission from rice fields is feasible through different management options (Wassmann et al. 1993). Among several options, intermittent drainage suppressed $\mathrm{CH}_{4}$ emission by changing soil redox conditions (Yagi et al. 1996). Although previous reports showed reduction in $\mathrm{CH}_{4}$ emissions from paddy fields due to midseason drainage (Minamikawa and Sakai 2006; Shiratori et al. 2007), $\mathrm{CO}_{2}$ and $\mathrm{N}_{2} \mathrm{O}$ emissions rates increased (Saito et al. 2005; Miyata et al. 2000).

Paddy field has a high capacity for $\mathrm{C}$ sequestration (Pan et al. 2004; Zheng et al. 2008; Lu et al. 2009; Shang et al. 2010) by converting atmospheric $\mathrm{CO}_{2}$ into stable organic $\mathrm{C}$ pools. However, the changes in soil $\mathrm{C}$ storage depend on the balance between $\mathrm{C}$ input and output. Therefore, net 
$\mathrm{CO}_{2}$ emission impact can be evaluated by $\mathrm{C}$ balance analysis. In general, the net exchanges of $\mathrm{CO}_{2}$ could be measured by soil organic $\mathrm{C}$ (SOC) changes over a subdecadal or decadal timescale (Pan et al. 2004; Lu et al. 2009). The NECB analysis is developed as a powerful tool to estimate soil $\mathrm{C}$ balance between $\mathrm{C}$ sequestration and $\mathrm{CO}_{2}$ emission (Chapin et al. 2006; Smith et al. 2010). This method has not been studied adequately in relation to CCB incorporation rates and water management. Therefore, it is necessary to find out the optimum rate of CCB incorporation and water management option for determination of NECB and net GWP during rice cultivation.

\section{Materials and methods}

\section{Field preparation for rice cultivation}

The experiment was carried out during June to October, 2013 in Gyeongsang National University $\left(36^{\circ} 50^{\prime} \mathrm{N}\right.$ and $128^{\circ} 26^{\prime}$ E), Jinju, South Korea. Soil was silt loam in texture with $20.4 \pm 3.9 \mathrm{~g} \mathrm{~kg}^{-1}$ organic matter, $0.70 \mathrm{~g} \mathrm{~kg}^{-1}$ total $\mathrm{N}, \mathrm{pH}$ $\left(1: 5, \quad \mathrm{H}_{2} \mathrm{O}\right) \quad 6.2 \pm 0.32$, and available $P \quad 34.37 \pm$ $1.35 \mathrm{mg} \mathrm{kg}^{-1}$. A mixture of barley (75\% of recommended dose, $\mathrm{RD}$ ) and vetch ( $25 \%$ of $\mathrm{RD}$ ) was broadcasted after rice harvesting in 2012 (Haque et al. 2013).

The experiment utilized four CCB rates $(0,3,6$ and $12 \mathrm{Mg} \mathrm{ha}^{-1}$, dry weight basis) as sub-plot treatments and two water regimes (intermittent drainage and continuous flooding) as main plot treatments and assigned in a split-plot design with three replications. Unit plot size was 10-m $\times 10-m$. In 1 June 2013 , the aboveground biomass of cover crop was harvested at 204 days after seeding, chopped (size 5-10 cm) manually, and applied at per treatment followed by mechanical mixing with soil 1 week before rice transplanting. In intermittent drainage, there was 5-7 cm water up to 21 days after transplanting (DAT) and no water was applied after 21 DAT for 30 days and then flooded again till 15 days before rice harvesting. In continuous flooding, 5-7 cm water depth was maintained till 15 days before paddy harvesting.

Four 21-day-old seedlings hill ${ }^{-1}$ of Dongjinbyeo (Japonica-type rice) were transplanted at $15-\times 30-\mathrm{cm}$ spacing on 8th June 2013. The RDs of chemical fertilizers (N-P-K $=90-20-48 \mathrm{~kg} \mathrm{ha}^{-1}$ ) were applied 1 day before rice transplanting (RDA 1999).

\section{Gas sampling and analyses}

A closed-chamber method was used to estimate $\mathrm{CH}_{4}, \mathrm{~N}_{2} \mathrm{O}$, and $\mathrm{CO}_{2}$ emissions (Rolston 1986; Ali et al. 2009; Haque et al. 2013, 2015a, b). The transparent glass chambers with a surface area of $62-\mathrm{cm} \times 62-\mathrm{cm} \times 112-\mathrm{cm}$ were placed permanently into the flooded soil after rice transplanting for monitoring $\mathrm{CH}_{4}$ and $\mathrm{N}_{2} \mathrm{O}$ emission rates. Eight rice plants were covered by each chamber. There were four holes at the bottom of the chamber to maintain water level at 5-7 cm above the soil surface. For $\mathrm{CO}_{2}$ gas sampling, a separate acrylic column chamber $(20-\times 20-\mathrm{cm})$ was placed near the transparent glass chambers between rice plants (Lou et al. 2004; Xiao et al. 2005; Iqbal et al. 2008). All chambers were kept open throughout the rice cultivation period except during gas sampling. The chamber was equipped with a circulating fan for gas mixing and a thermometer to monitor the inside temperature during sampling time.

Air-gas sampling was carried out using 50-ml airtight syringe at 0 and $30 \mathrm{~min}$ after closing the top of the chamber. Gas samplings were carried out at 8 a.m., 12 and 16 p.m. in a day to get average $\mathrm{CH}_{4}, \mathrm{~N}_{2} \mathrm{O}$, and $\mathrm{CO}_{2}$ emission rates. Gas samples from each treatment were drawn off in triplicate and collected samples were immediately transferred into $30-\mathrm{ml}$ vacuum glass vials sealed with a butyl rubber septum for analyses.

Methane, $\mathrm{N}_{2} \mathrm{O}$, and $\mathrm{CO}_{2}$ concentrations in the collected air samples were measured by Gas Chromatography (Shimadzu, GC-2010, Japan) packed with Porapak NQ column (Q 80-100 mesh) equipped with flame ionization detector (FID) and thermal conductivity detector (TCD), respectively. Temperatures for the column, injector, and detector were adjusted at 100,200 and $200{ }^{\circ} \mathrm{C}$ and 45,75 and $270{ }^{\circ} \mathrm{C}$ for $\mathrm{CH}_{4}, \mathrm{~N}_{2} \mathrm{O}$, and $\mathrm{CO}_{2}$ analyses, respectively. Helium and $\mathrm{H}_{2}$ gases were used as carrier and burning gases for $\mathrm{CH}_{4}, \mathrm{~N}_{2} \mathrm{O}$, and $\mathrm{CO}_{2}$ analyses, respectively.

\section{Estimation of $\mathrm{CH}_{4}, \mathrm{CO}_{2}$ and $\mathrm{N}_{2} \mathrm{O}$ emissions}

Methane, $\mathrm{CO}_{2}$, and $\mathrm{N}_{2} \mathrm{O}$ emission rates were calculated according to Rolston (1986) and Lou et al. (2004) as follows:

$F=\rho \times(V / A) \times(\Delta c / \Delta t) \times(273 / T)$

where $F$ is the $\mathrm{CH}_{4}, \mathrm{CO}_{2}\left(\mathrm{mg} \mathrm{m}^{-2} \mathrm{~h}^{-1}\right.$ ), and $\mathrm{N}_{2} \mathrm{O}$ flux ( $\mu \mathrm{g}$ $\mathrm{N}_{2} \mathrm{O} \mathrm{m}^{-2} \mathrm{~h}^{-1}$ ), $\rho$ is the gas density of $\mathrm{CH}_{4}, \mathrm{CO}_{2}$, and $\mathrm{N}_{2} \mathrm{O}$ under standardized state $\left(\mathrm{mg} \mathrm{cm}^{-3}\right), V$ is the volume of chamber $\left(\mathrm{m}^{3}\right)$, ' $A$ ' is the surface area of chamber $\left(\mathrm{m}^{2}\right), \Delta c$ l $\Delta t$ is the rate of increase of $\mathrm{CH}_{4}, \mathrm{CO}_{2}$, and $\mathrm{N}_{2} \mathrm{O}$ gas concentrations in the chamber $\left(\mathrm{mg} \mathrm{m}^{-3} \mathrm{~h}^{-1}\right)$, and $T$ is the absolute temperature plus temperature $\left({ }^{\circ} \mathrm{C}\right)$ of the chamber.

Seasonal $\mathrm{CH}_{4}, \mathrm{CO}_{2}$, or $\mathrm{N}_{2} \mathrm{O}$ flux for crop growing period was computed as reported by Singh et al. (1999).

Seasonal $\mathrm{CH}_{4}, \mathrm{CO}_{2}$, and $\mathrm{N}_{2} \mathrm{O}$ flux $=\sum_{i}^{n}\left(R_{i} \times D_{i}\right)$,

where $R_{i}$ is the rate of $\mathrm{CH}_{4}, \mathrm{CO}_{2}$, and $\mathrm{N}_{2} \mathrm{O}$ flux $\left(\mathrm{g} \mathrm{m}^{-2} \mathrm{~d}^{-1}\right)$ in the $i$ th sampling period, $D_{i}$ is the number of days in the $i$ th sampling period, and $\mathrm{n}$ is the number of samplings. 


\section{Estimation of NECB}

We have summarized the findings of Ciais et al. (2010); Smith et al. (2010); Jia et al. (2012); Ma et al. (2013); Haque et al. (2015a) for determination of NECB as follows:

$$
\begin{aligned}
& \mathrm{NECB}= \mathrm{GPP}-R_{\mathrm{e}}-\text { Harvest }-\mathrm{CH}_{4} \\
&+ \text { Green manure } \\
& \mathrm{GPP}= \mathrm{NPP}+R_{\mathrm{a}} \\
& R_{\mathrm{e}}=R_{\mathrm{a}}+R_{\mathrm{h}}
\end{aligned}
$$

where GPP, NPP, $R_{\mathrm{e}}, R_{\mathrm{a}}$, and $R_{\mathrm{h}}$ represent gross primary production, net primary production, ecosystem respiration, autotrophic respiration, and heterotrophic respiration, respectively. The Harvest includes rice straw and grains and Green manure $\mathrm{C}$ inputs were calculated from CCB rates.

Equation (1) was converted to Eq. (4) using Eqs. (2) and (3) as follows:

$\mathrm{NECB}=\mathrm{NPP}-R_{\mathrm{h}}-$ Harvest $-\mathrm{CH}_{4}+$ Green manure

The NPP was estimated according to Smith et al. (2010).

\section{Net GWP}

The net GWP was estimated according to Ma et al. (2013) and Haque et al. (2015a).

\section{Rice plant and soil characteristics}

Rice grain yield was determined at harvesting. The redox potential of paddy soil was measured one time for every 7 days by Eh meter (PRN-41, DKK-TOA Corporation) and continued throughout the rice-growing period. The electrode was permanently installed into soil at $5-\mathrm{cm}$ depth. Soil temperature also was recorded one time for 7 days using a thermometer placed at a soil depth of $3-5 \mathrm{~cm}$ during rice cultivation. Soil samples were collected from surface layer $(0-15 \mathrm{~cm}$ depth), air-dried, and sieved through $<2 \mathrm{~mm}$ mesh for the analyses of $\mathrm{pH}\left(1: 5, \mathrm{H}_{2} \mathrm{O}\right)$, total organic C (Allison 1965), and total N (Kjeldahl method). Available phosphorus was determined by Lancaster method (RDA 1988).

\section{Dissolve organic carbon and microbial organic carbon}

Dissolved organic C (DOC) was extracted from fresh soil using cold water (Lu et al. 2011) and microbial biomass carbon (MBC) was measured by chloroform fumigationextraction method (Vance et al. 1987; Öhlinger 1996).

\section{Statistical analysis}

Statistical analyses were done using SAS software (SAS Institute 1995). A two-way ANOVA was carried out to compare the treatment means. Fisher's protected least significant difference (LSD) was calculated at 0.05 probability for making treatment mean comparisons.

\section{Results}

\section{Changes in $\mathrm{CH}_{4}-\mathrm{C}$ emission}

The $\mathrm{CH}_{4}-\mathrm{C}$ emission pattern was significantly influenced by water management (Fig. 1). Its emission pattern was similar up to 21 DAT due to continuous flooded conditions under variable $\mathrm{CCB}$ incorporation rates. In continuous flooding, the high $\mathrm{CH}_{4}-\mathrm{C}$ emission peak was observed at about 30 DAT. In intermittent drainage, the initial $\mathrm{CH}_{4}-\mathrm{C}$ emission peak was high, which decreased significantly with the withdrawal of irrigation water. Increasing rate of CCB application significantly increased $\mathrm{CH}_{4}-\mathrm{C}$ emission under both the water management conditions. Methane emission rates dropped to atmospheric levels at grain maturation stage, irrespective of irrigation and biomass applications (Fig. 1). In continuous flooding systems, seasonal $\mathrm{CH}_{4}-\mathrm{C}$ flux was $180 \mathrm{~kg} \mathrm{ha}^{-1}$ in control plot (no CCB incorporation) that significantly increased $(P<0.05)$ by $635 \%$ with $12 \mathrm{Mg} \mathrm{ha}^{-1} \mathrm{CCB}$ incorporation. Similar trend was observed with intermittent drainage conditions. However, 30 days drainage period significantly reduced total $\mathrm{CH}_{4}-\mathrm{C}$ fluxes by $54-58 \%$ irrespective of CCB incorporation rates compared to continuous flooding (Table 1).

\section{Changes of $\mathrm{CO}_{2}-\mathrm{C}$ emission}

The $\mathrm{CO}_{2}-\mathrm{C}$ emission rate was comparatively lower at initial rice growth stage and then increased significantly with the age of plants (Fig. 1). The highest $\mathrm{CO}_{2}-\mathrm{C}$ emission rate was observed at around $60 \mathrm{DAT}$ and then gradually declined to background level under continuous flooding conditions. The $\mathrm{CO}_{2}-\mathrm{C}$ emission pattern in intermittent drainage was significantly different than continuous flooding (Fig. 1) in which the highest peak was observed at about 40 DAT. In general, the $\mathrm{CO}_{2}-\mathrm{C}$ emission rates were much higher with intermittent drainage than with continuous flooding. About $1.05-2.05 \mathrm{Mg} \mathrm{ha}^{-1}$ of $\mathrm{CO}_{2}-\mathrm{C}$ emission was estimated under continuous flooding but it was about $1.26-2.74 \mathrm{Mg} \mathrm{ha}{ }^{-1} \mathrm{CO}_{2}-\mathrm{C}$ with intermittent drainage (Table 1). The intermittent drainage 


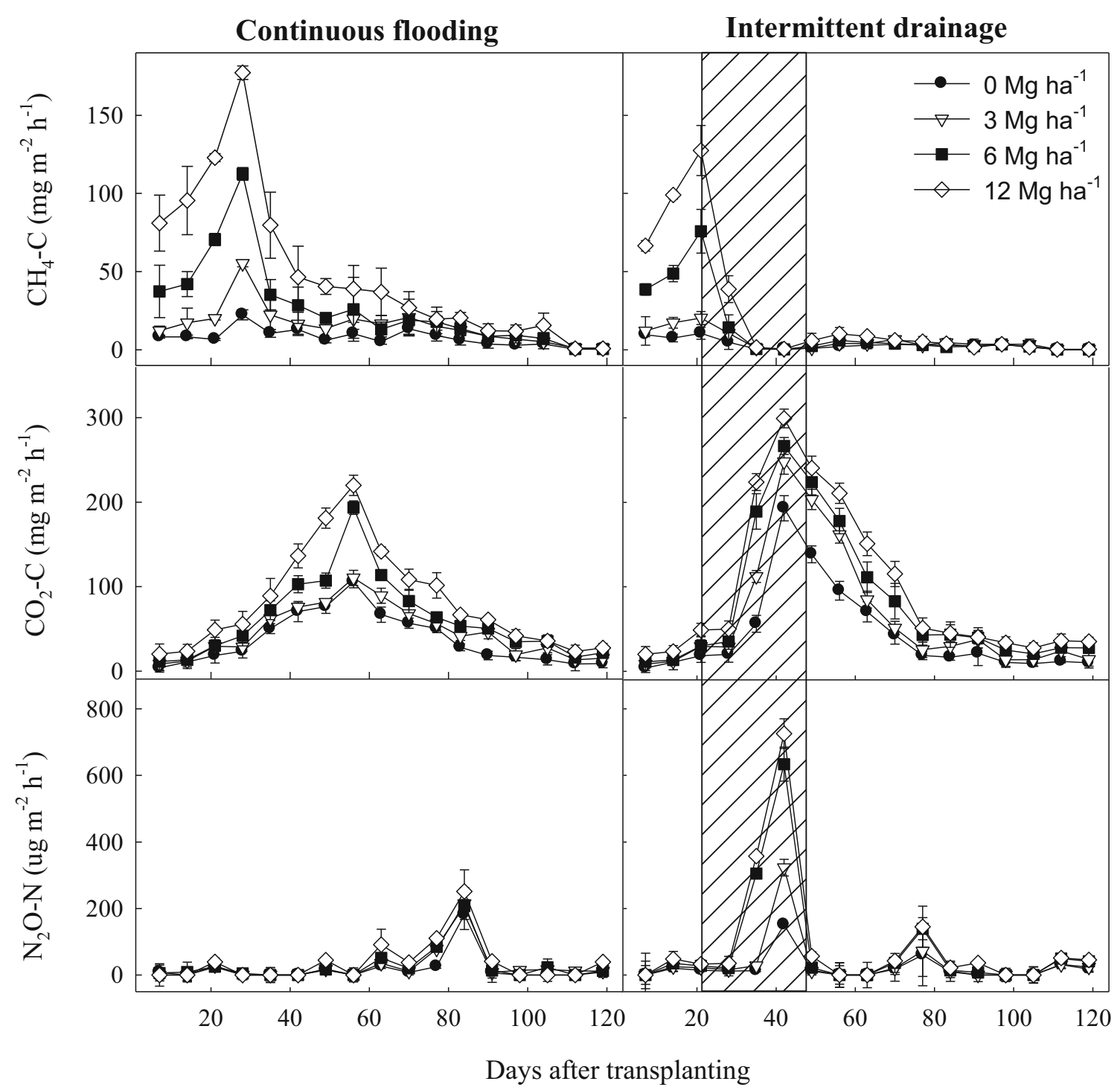

Fig. 1 Changes of $\mathrm{CH}_{4}-\mathrm{C}, \mathrm{CO}_{2}-\mathrm{C}$, and $\mathrm{N}_{2} \mathrm{O}-\mathrm{N}$ emission rates under continuous flooding and intermittent drainage having variable levels of cover crop biomass incorporation for rice cultivation

increased $19-33 \%$ of total $\mathrm{CO}_{2}-\mathrm{C}$ flux than continuous flooding.

\section{Changes of $\mathrm{N}_{2} \mathrm{O}-\mathrm{N}$ emission}

There was fluctuating $\mathrm{N}_{2} \mathrm{O}$ emission irrespective of water regimes and CCB application rates (Fig. 1). However, $\mathrm{N}_{2} \mathrm{O}$ emission rates were significantly $(P<0.0 \mathrm{I})$ higher during intermittent drainage period compared to continuous flooding. Seasonal $\mathrm{N}_{2} \mathrm{O}$ fluxes in continuous flooding varied from 0.52 to $2.04 \mathrm{Mg} \mathrm{ha}^{-1}$ depending on CCB incorporation rates, which were $0.73-2.99 \mathrm{Mg} \mathrm{ha}^{-1}$ with intermittent drainage conditions (Table 1).

\section{Changes in NECB}

Rice cultivation significantly increased the NPP and total organic C (TOC) input depending on CCB rates. Rice biomass production contributed ca. 59-99\% of TOC input, but 1-41\% was contributed by fertilizer and CCB (Table 1). In continuous flooding and intermittent drainage, TOC output was about 6.15-9.34 and 6.10-9.40 $\mathrm{Mg} \mathrm{C}^{-1}$, respectively. Rice harvest removed about $66-80 \%$ of TOC and about $20-24 \%$ of mineralized $\mathrm{C}$ loss. The $\mathrm{CO}_{2}-\mathrm{C}$ loss was 2-6 and 4-12 times greater than $\mathrm{CH}_{4}-\mathrm{C}$ loss under both the water regimes. As a result, the NECB was -275 to $2959 \mathrm{~kg} \mathrm{C} \mathrm{ha}{ }^{-1}$ under continuous flooding and -402 to 
Table 1 Seasonal organic carbon input and output as influenced by water regimes and biomass incorporation rates

\begin{tabular}{|c|c|c|c|c|c|c|c|c|c|c|}
\hline \multirow[t]{2}{*}{ Irrigation system (A) } & \multirow{2}{*}{$\begin{array}{l}\text { Biomass application } \\
\left(\mathrm{Mg} \mathrm{ha}^{-1}, \mathrm{dw}\right)(\mathrm{B})\end{array}$} & \multicolumn{4}{|c|}{ Organic $\mathrm{C}$ input $\left(\mathrm{kg} \mathrm{C} \mathrm{ha}^{-1}\right)(\mathrm{C})$} & \multicolumn{4}{|c|}{ Organic $\mathrm{C}$ output $\left(\mathrm{kg} \mathrm{C} \mathrm{ha}^{-1}\right)$ (D) } & \multirow{2}{*}{$\begin{array}{l}\text { NECB } \\
\left(\mathrm{kg} \mathrm{C} \mathrm{ha}^{-1}\right) \\
(\mathrm{C}-\mathrm{D})\end{array}$} \\
\hline & & NPP & Fertilizer & Biomass & Sum & $\mathrm{CO}_{2}-\mathrm{C}$ & $\mathrm{CH}_{4}-\mathrm{C}$ & Harvest & Sum & \\
\hline \multirow[t]{4}{*}{ Continuous flooding } & 0 & 5859 & 20 & 0 & 5879 & 1054 & 180 & 4920 & 6154 & -275 \\
\hline & 3 & 8315 & 20 & 1276 & 9611 & 1278 & 308 & 7017 & 8603 & 1008 \\
\hline & 6 & 7614 & 20 & 2505 & 10,139 & 1755 & 746 & 6387 & 8888 & 1251 \\
\hline & 12 & 7317 & 20 & 4963 & 12,300 & 2056 & 1144 & 6141 & 9341 & 2959 \\
\hline \multirow[t]{4}{*}{ Intermittent drainage } & 0 & 5680 & 20 & 0 & 5700 & 1256 & 105 & 4741 & 6102 & -402 \\
\hline & 3 & 8154 & 20 & 1276 & 9450 & 1846 & 176 & 6856 & 8878 & 572 \\
\hline & 6 & 7564 & 20 & 2505 & 10,089 & 2300 & 437 & 6387 & 9124 & 965 \\
\hline & 12 & 7225 & 20 & 4963 & 12,208 & 2737 & 623 & 6049 & 9409 & 2799 \\
\hline \multicolumn{11}{|l|}{2 way ANOVA } \\
\hline A & & $*$ & NS & NS & NS & $* * *$ & $* * *$ & NS & $* *$ & $* * *$ \\
\hline B & & $* * *$ & NS & $* * *$ & $* * *$ & $* * *$ & $* * *$ & $*$ & $* * *$ & $* * *$ \\
\hline$A \times B$ & & $* * *$ & NS & NS & NS & $* * *$ & $* * *$ & NS & $* * *$ & $* * *$ \\
\hline
\end{tabular}

NS means not significant

$*, * *$, and $* * *$ mean significant at 5, 1 and $0.1 \%$ levels, respectively

$2799 \mathrm{~kg} \mathrm{C} \mathrm{ha}^{-1}$ under intermittent drainage conditions. However, the intermittent drainage significantly reduced seasonal NECB by 6-46\% compared to continuous flooding.

\section{Changes in net GWP}

The CCB incorporation rates and irrigation water regimes were the most influential factors for $\mathrm{CH}_{4}$ emission and net GWP (Figs. 1, 2). Under continuous flooding conditions, the contribution of seasonal $\mathrm{CH}_{4}$ flux to the net GWP was $71-75 \%$ followed by estimated NECB $\left(23-28 \% \mathrm{CO}_{2}\right)$. Nitrous oxide flux contributed only $1-2 \%$ to GWP.

Intermittent drainage conditions significantly reduced $\mathrm{CH}_{4}$ flux by contributing about $26-45 \%$ of net GWP, but increased the proportion of $\mathrm{N}_{2} \mathrm{O}$ to total GWP by 0.50-1.2\%. More importantly, 30-day intermittent drainage significantly reduced net GWPs by $35-58 \%$ compared to continuous flooding conditions (Fig. 2).

\section{Rice yield and soil properties}

Cover crop biomass incorporation significantly stimulated rice yield. Under continuous flooding, grain yield was $5.7 \mathrm{Mg} \mathrm{ha}^{-1}$ in control that increased sharply with increasing $\mathrm{CCB}$ application rates. Grain yield was not significantly influenced by water regimes (Fig. 3).

Organic matter content increased significantly with higher rates of $\mathrm{CCB}$ irrespective of water regimes (Table 2). Similarly, total N and MBC increased significantly due to higher rates of CCB incorporation compared to control. No such variations were observed because of irrigation water regimes. Soil mean Eh values and DOC were significant different under water regimes and CCB incorporation during rice cultivation (Table 2). Soil mean temperature was not influenced under $\mathrm{CCB}$ incorporation but increased significantly under water regimes.

\section{Discussion}

The removal of paddy field water for 30 days significantly reduced $\mathrm{CH}_{4}-\mathrm{C}$ emission (54-58 \%), which is consistent with the findings of Kim et al. (2014); Itoh et al. (2011); Ma and Lu (2011); Hadi et al. (2010); Sass et al. (1992); Yagi et al. (1996); Adhya et al. (1994). They reported 43-58\% reduction of $\mathrm{CH}_{4}$ emission through intermittent drainage. This implies that this is the most promising strategy for reducing $\mathrm{CH}_{4}-\mathrm{C}$ emissions from rice fields. Like Cai et al. (2001); Minamikawa and Sakai (2006); Sharma et al. (2016), we also found greater $\mathrm{CH}_{4}-\mathrm{C}$ emissions under continuous flooding than intermittent drainage conditions. Intermittent drainage changed $\mathrm{Eh}$ values and DOC contents (Table 2). There was increasing diffusion of gases and availability of $\mathrm{O}_{2}$, reduced methanogen but increased methanotroph populations, and thus responsible for effective reduction of $\mathrm{CH}_{4}-\mathrm{C}$ emission from paddy field (Ma and Lu 2011). However, MBC at harvest did not vary because of water regimes (Table 2) in our investigation. Asakawa et al. (1997) reported that intermittent drainage reduces $\mathrm{CH}_{4}-\mathrm{C}$ production by methanogens or methanotrophs. We found significant increase in $\mathrm{CO}_{2}-\mathrm{C}$ and $\mathrm{N}_{2} \mathrm{O}-\mathrm{N}$ emissions because of intermittent drainage (Fig. 1). 
Fig. 2 Net global warming potential as influenced by continuous flooding and intermittent drainage having variable levels of cover crop biomass incorporation for rice cultivation

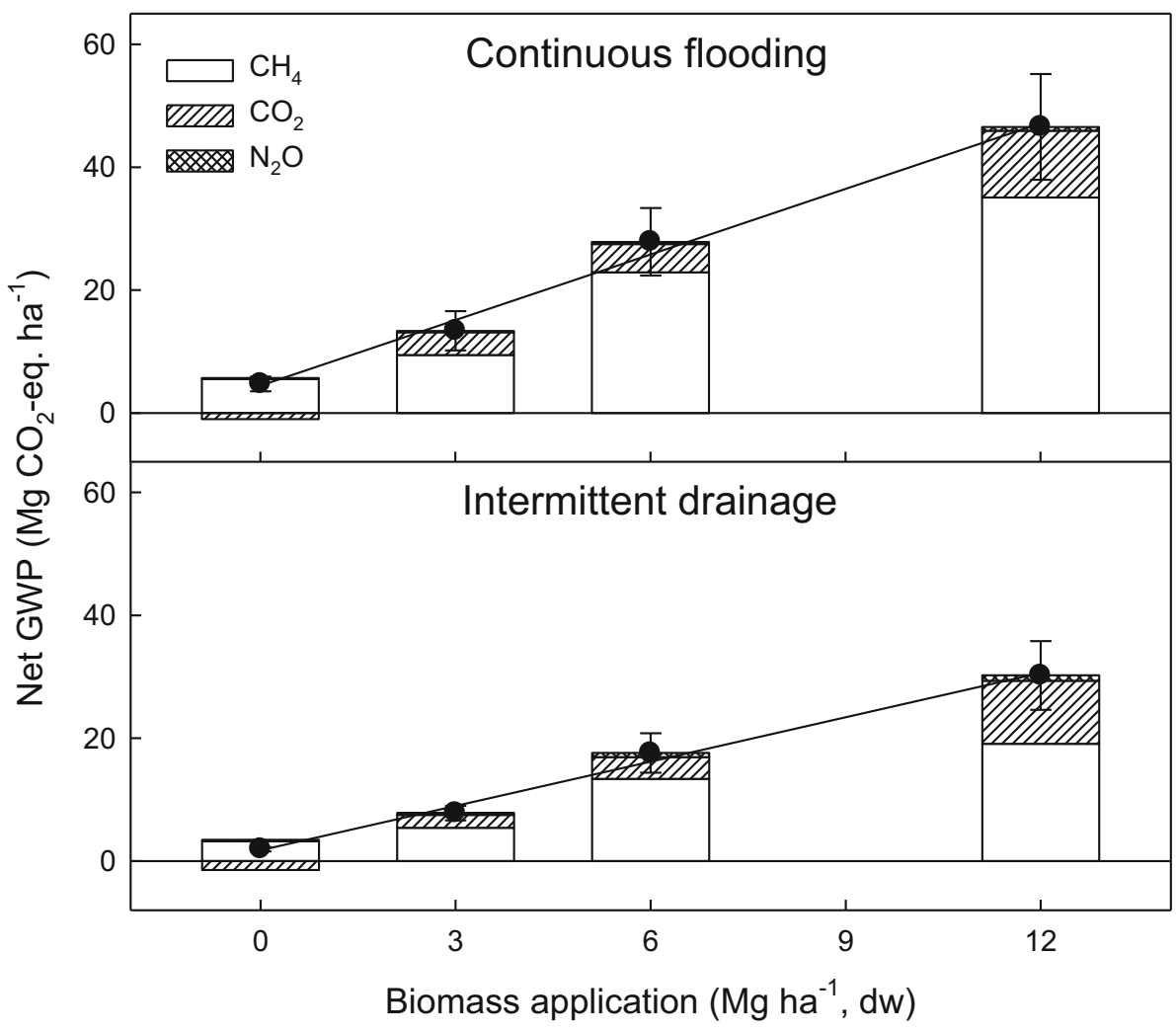

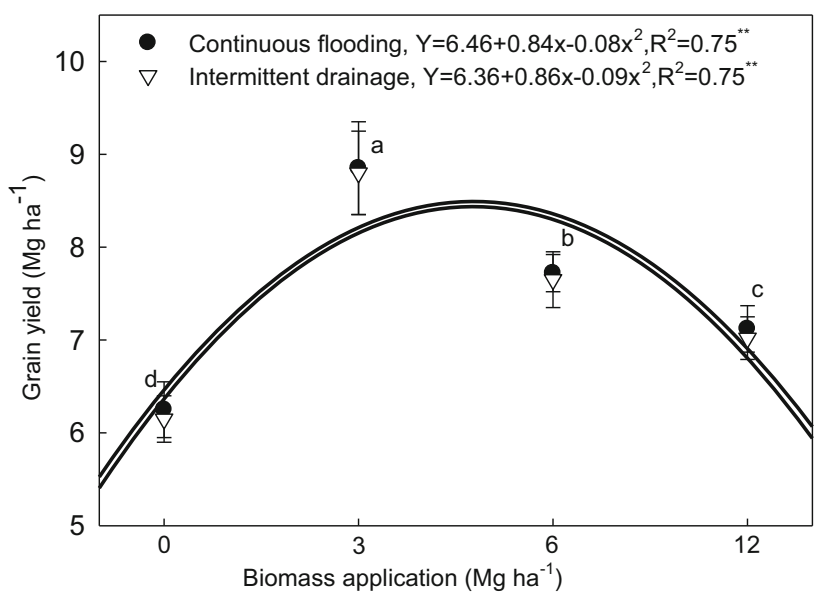

Fig. 3 Changes of rice grain yield under continuous flooding and intermittent drainage having variable levels of cover crop biomass incorporation for rice cultivation

The NECB increased with greater CCB incorporation rates under both the water regimes compared to control (Table 1). The positive value of NECB represents ecosystem $\mathrm{C}$ gain after crop harvest on seasonal scale. What we found was that the NECB was mainly contributed by the input and output of $\mathrm{C}$, irrespective of water regimes. In Korean paddy soil, most of the rice straw is removed as cattle feed and is considered as total
$\mathrm{C}$ output. The removal of $\mathrm{C}$ by harvesting covered around $78-80 \%$ of total $\mathrm{C}$ output followed by soil respiration (20-22\%) under control conditions (no use of CCB). Although intermittent drainage significantly increased the respiratory C loss by $91-105 \%$ compared to continuous flooding, the net primary production (NPP) of $\mathrm{C}$ was not influenced by water regimes (Table 1). Moreover, intermittent drainage effectively reduced $\mathrm{CH}_{4}-\mathrm{C}$ emission, but its contribution to NECB was negligible. The NECB was -275 to $2959 \mathrm{~kg} \mathrm{Cha}^{-1}$ in continuous flooded plots indicating that this amount of $\mathrm{CO}_{2}-\mathrm{C}$ was sequestrated from the atmosphere. The intermittent drainage also significantly reduced seasonal NECB by $6-46 \%$ compared to continuous flooding. It means that intermittent drainage is less effective for $\mathrm{C}$ sequestration. There will be loss of soil $\mathrm{C}$ if chemical fertilizers are used only for growing rice irrespective of water regimes (Table 1), although it would be about $46 \%$ more with intermittent drainage than continuous flooding. This implies that soil quality will be deteriorating in the long run under such conditions. If $3 \mathrm{Mg} \mathrm{ha}^{-1} \mathrm{CCB}$ is incorporated, soil $\mathrm{C}$ balance becomes positive indicating improvement of soil health. Although soil $\mathrm{C}$ balance increased with greater rates of CCB incorporation, grain yield reduced significantly. So, incorporation of $3 \mathrm{Mg} \mathrm{ha}^{-1} \mathrm{CCB}$ is suitable for economic yield and soil health improvement along with reduction of net GWP. 
Table 2 Soil properties at harvest and during rice cultivation as influenced by water regimes and cover crop biomass incorporation rates

\begin{tabular}{|c|c|c|c|c|c|c|c|c|}
\hline $\begin{array}{l}\text { Irrigation system } \\
\text { (A) }\end{array}$ & $\begin{array}{l}\text { Biomass application } \\
\left(\mathrm{Mg} \mathrm{ha}^{-1}, \mathrm{dw}\right)(\mathrm{B})\end{array}$ & $\begin{array}{l}\text { Total organic } \\
\text { matter }\left(\mathrm{g} \mathrm{kg}^{-1}\right)\end{array}$ & $\begin{array}{l}\text { Total N } \\
\left(\mathrm{g} \mathrm{kg}^{-1}\right)\end{array}$ & $\begin{array}{l}\mathrm{C} / \mathrm{N} \\
\text { ratio }\end{array}$ & $\begin{array}{l}\text { Microbial } \\
\text { biomass C } \\
\left(\mathrm{g} \mathrm{kg}^{-1}\right)\end{array}$ & $\begin{array}{l}\text { Mean } \\
\text { temperature } \\
\left({ }^{\circ} \mathrm{C}\right)\end{array}$ & $\begin{array}{l}\text { Mean Eh } \\
\text { values }(\mathrm{Mv})\end{array}$ & $\begin{array}{l}\text { Mean DOC } \\
\left(\mathrm{mg} \mathrm{kg}^{-1}\right)\end{array}$ \\
\hline \multirow{4}{*}{$\begin{array}{l}\text { Continuous } \\
\text { flooding }\end{array}$} & 0 & 4.7 & 0.7 & 6.71 & 0.112 & 25 & -244 & 250 \\
\hline & 3 & 5.99 & 0.75 & 7.98 & 0.205 & 25.2 & -254 & 253 \\
\hline & 6 & 7.67 & 0.77 & 9.96 & 0.415 & 25.4 & -277 & 277 \\
\hline & 12 & 8.78 & 0.8 & 10.97 & 0.625 & 25.6 & -280 & 279 \\
\hline \multirow{4}{*}{$\begin{array}{l}\text { Intermittent } \\
\text { drainage }\end{array}$} & 0 & 4.59 & 0.7 & 6.55 & 0.115 & 26.1 & -88 & 193 \\
\hline & 3 & 5.87 & 0.86 & 6.83 & 0.21 & 26.2 & -112 & 229 \\
\hline & 6 & 7.61 & 0.77 & 9.88 & 0.435 & 26.3 & -126 & 242 \\
\hline & 12 & 8.72 & 0.82 & 10.63 & 0.654 & 26.7 & -144 & 251 \\
\hline \multicolumn{9}{|l|}{2 way ANOVA } \\
\hline \multicolumn{2}{|c|}{ Irrigation system (A) } & NS & NS & NS & NS & NS & $* * *$ & $* * *$ \\
\hline \multicolumn{2}{|c|}{ Biomass application rate (B) } & $* * *$ & $*$ & $* * *$ & $* * *$ & NS & $* * *$ & $* * *$ \\
\hline \multicolumn{2}{|c|}{$\mathrm{A} \times \mathrm{B}$} & NS & NS & NS & NS & NS & $* * *$ & $* * *$ \\
\hline \multicolumn{2}{|l|}{$\mathrm{CV}(\%)$} & 0.26 & 0.06 & 0.77 & 0.02 & 1.04 & 137.5 & 35.95 \\
\hline
\end{tabular}

$N S$ means not significant

$*$ and $* * *$ mean significant at 5 and $0.1 \%$ levels, respectively

It has been delineated that exchange between $\mathrm{N}_{2} \mathrm{O}-\mathrm{N}$ and $\mathrm{CH}_{4}-\mathrm{C}$ emissions takes place during midseason drainage and intermittent drainage (Cai et al. 1997; Hua et al. 1997; Yan et al. 2000). Our investigation revealed significantly higher $\mathrm{N}_{2} \mathrm{O}-\mathrm{N}$ emission rates during intermittent drainage with variable CCB incorporation rates, and thus significantly contributed to total $\mathrm{N}_{2} \mathrm{O}-\mathrm{N}$ flux (Fig. 1). Draining the paddy field creates suitable environment for greater availability of $\mathrm{O}_{2}$, and thus for the production of $\mathrm{N}_{2} \mathrm{O}-\mathrm{N}$ either from nitrification or denitrification (Xiong et al. 2007).

In continuous flooding, $\mathrm{CH}_{4}$ contributed $71-75 \%$ of net GWP followed by NECB $\left(23-28 \% \mathrm{CO}_{2}\right)$ irrespective of CCB incorporation rates (Fig. 2). The contribution of $\mathrm{N}_{2} \mathrm{O}$ was very negligible (1-2\%). Intermittent drainage reduced the contribution of $\mathrm{CH}_{4}$ to net GWP by $26-45 \%$, while contribution of $\mathrm{CO}_{2}$ and $\mathrm{N}_{2} \mathrm{O}$ increased by $2-10$ and 1-2\%, respectively. Nonetheless, intermittent drainage reduced net GWP by $35-58 \%$ compared to continuous flooding under same CCB incorporation rate, mainly due to large decrease in $\mathrm{CH}_{4}$ emission.

Existing literature shows that GWP can be reduced through intermittent drainage of paddy fields (Maris et al. 2016; Win et al. 2015; Sharma et al. 2016) but no NECB has been delineated by others in combination with cover crop biomass incorporation rates and intermittent drainage conditions. Our findings indicate that we can not only reduce greenhouse gas emission from paddy soil, but also can maintain soil health for better crop production sustainably. Such information might be useful for similar rice growing environments of the world.

\section{Conclusion}

Intermittent drainage decreased NECB by $6-46 \%$ compared to continuous flooding. Moreover, it reduced $\mathrm{CH}_{4}-\mathrm{C}$ emission rates and net GWP by about $54-58$ and $35-58 \%$, respectively. These imply that intermittent drainage and use of $3 \mathrm{Mg} \mathrm{ha}^{-1} \mathrm{CCB}$ can be a good management option for reducing $\mathrm{CH}_{4}-\mathrm{C}$ emission and net GWP along with profitable rice grain yield.

Acknowledgments This work was carried out with the support of "Cooperative Research Program for Agriculture Science \& Technology Development (Project No: PJ009980012016, Project tile: Development of $\mathrm{CO}_{2}$ emission factor caused by use of urea and lime according to 2006 new guideline)", Rural Development Administration (RDA), Republic of Korea.

Open Access This article is distributed under the terms of the Creative Commons Attribution 4.0 International License (http://crea tivecommons.org/licenses/by/4.0/), which permits unrestricted use, distribution, and reproduction in any medium, provided you give appropriate credit to the original author(s) and the source, provide a link to the Creative Commons license, and indicate if changes were made.

\section{References}

Adhya TK, Rath AK, Gupta PK, Rao VR, Das SN, Parida KM, Parashar DC, Sethunathan N (1994) Methane emission from flooded rice fields under irrigated conditions. Biol Fert Soils $18: 245-248$

Ali MA, Lee CH, Lee YB, Kim PJ (2009) Silicate fertilization in notillage rice farming for mitigation of methane emission and increasing rice productivity. Agric Ecosyst Environ 132:16-22 
Allison LE (1965) Organic carbon. In: Black CA (ed) Methods of soil analysis part II. Am. Soc. Agron. Inc. Publ., Madison, pp 1367-1376

Asakawa S, Koga Y, Hayono K (1997) Enumeration of methanogenic bacteria in paddy field soil by the most probable number (MPN) method. Soil Microorgan 47:31-36

Bouwman AF (1990) Introduction. In: Bouwman AF (ed) Soil and the greenhouse effect. Wiley, Chichester, pp 25-32

Cai ZC, Xing G, Yan X, Xu H, Tsuruta H, Yagi K, Minami K (1997) Methane and nitrous oxide emissions from paddy fields as affected by nitrogen fertilizers and water management. Plant Soil 196:7-14

Cai Z, Laughlin R, Stevens RJ (2001) Nitrous oxide and dinitrogen emissions from soil under different water regimes and straw amendment. Chemosphere 42:113-121

Chapin FS, Woodwell G, Randerson J, Rastetter EB, Lovett G, Baldocchi D, Clark D, Harmon M, Schimel DS, Valentini R (2006) Reconciling carbon-cycle concepts, terminology, and methods. Ecosystems 9:1041-1050

Ciais P, Wattenbach M, Vuichard N, Smith P, Piao SL, Don A, Luyssaert S, Janssens I, Bondeau A, Dechow R (2010) The European carbon balance. Part 2: croplands. Global Chan Biol 16:1409-1428

Garcia JL, Patel BCK, Ollivier B (2000) Taxonomic, phylogenetic and ecological diversity of methanogenic archaeal. Anaerobe 6:205-226

Hadi A, Inubushi K, Yagi K (2010) Effect of water management on greenhouse gas emissions and microbial properties of paddy soils in Japan and Indonesia Paddy. Water Environ 8:319-324

Haque MM, Kim SY, Pramanik P, Kim GY, Kim PJ (2013) Optimum application level of winter cover crop biomass as green manure under considering methane emission and rice productivity in paddy soil. Biol Fert Soils 49:487-493

Haque MM, Kim SY, Ali MA, Kim PJ (2015a) Contribution of greenhouse gas emissions during cropping and fallow seasons on total global warming potential in mono-rice paddy soils. Plant Soil 387:251-264

Haque MM, Kim SY, Kim GW, Kim PJ (2015b) Optimization of removal and recycling ratio of cover crop biomass using carbon balance to sustain soil organic carbon stocks in a mono-rice paddy system. Agric Ecosyst Environ 207:119-125

Haris RC, Gorham E, Sabacher DI, Bartlett KB, Flebbe PA (1985) Methane flux from northern peatland. Nature 315:652-654

Hua X, Guangxi X, Cai ZC, Tsuruta H (1997) Nitrous oxide emissions from three rice paddy fields in China. Nutr Cycl Agroecosyst 49:23-28

IPCC (2007) Technical summary. In: Solomon S, Qin D, Manning M, Chen Z, Marquis M, Averyt KB, Tignor M, Miller HL (eds) Climate change: the physical science basis. Contribution of Working Group 1 to the forth assessment report of the intergovernmental panel on climate change. Cambridge University Press, Cambridge

Iqbal J, Ronggui H, Lijun D, Lan L, Shan L, Tao C, Leilei R (2008) Differences in soil $\mathrm{CO}_{2}$ flux between different land use types in mid-subtropical China. Soil Biol Biochem 40:2324-2333

Itoh M, Sudo S, Mori S, Saito H, Yoshida T (2011) Mitigation of methane emissions from paddy fields by prolonging midseason drainage. Agric Ecosyst Environ 141:359-372

Janzen HH (2004) Carbon cycling in earth systems a soil science perspective. Agric Ecosyst Environ 104:399-417

Jia JX, Ma YC, Xiong ZQ (2012) Net ecosystem carbon budget, net global warming potential and greenhouse gas intensity in intensive vegetable ecosystems in China. Agric Ecosyst Environ 150:27-37
Kim SY, Lee CH, Gutierrez J, Kim PJ (2013) Contribution of winter cover crop amendments on global warming potential in rice paddy soil during cultivation. Plant Soil 366:273-286

Kim GY, Gutierrez J, Jeong HC, Lee JS, Haque MM, Kim PJ (2014) Effect of intermittent drainage on methane and nitrous oxide emissions under different fertilization in a temperate paddy soil during rice cultivation. J Korean Soci Appl Biol Chem 57:229-236

Lee YH (2010) Evaluation of no-tillage rice cover crop cropping system for organic farming. Korean J Soil Sci Fert 43:200-208

Lou Y, Li Z, Zhang T, Liang Y (2004) $\mathrm{CO}_{2}$ emissions from subtropical arable soils of China. Soil Biol Biochem 36:1835-1842

Lu F, Wang X, Han B, Ouyang Z, Duan X, Zheng H, Miao H (2009) Soil carbon sequestrations by nitrogen fertilizer application, straw return and no-tillage in China's cropland. Global Chan Biol 15:281-305

Lu X, Fan J, Yan Y, Wang X (2011) Soil water soluble organic carbon under three alpine grassland types in Northern Tibet, China. African J Agric Res 6:2066-2071

Ma K, Lu YH (2011) Regulation of microbial methane production and oxidation by intermittent drainage in rice field soil. FEMS Microbiol Ecol 75:446-456

Ma YC, Kong XW, Yang B, Zhang XL, Yan XY, Yang JC, Xiong ZQ (2013) Net global warming potential and greenhouse gas intensity of annual rice-wheat rotations with integrated soil crop system management. Agric Ecosyst Environ 164:209-219

Maris SC, Teira-Esmatges MR, Català MM (2016) Influence of irrigation frequency on greenhouse gases emission from a paddy soil. Paddy Water Environ 14:199-210

Minamikawa K, Sakai N (2006) The practical use of water management based on soil redox potential for decreasing methane emission from a paddy field in Japan. Agric Ecosyst Environ 116:181-188

Miyata A, Leuning R, Denmead OT, Kim J, Harazono Y (2000) Carbon dioxide and methane fluxes from an intermittently flooded paddy field. Agric Forest Meteorol 102:287-303

Neue HU, Roger PA (1993) Rice agriculture; factors affecting emissions. In: Khalil MAK (ed) atmospheric methane: sources sinks and role in global change. Springer, Berlin, pp 254-298

Neue HU, Wassmann R, Kludze HK, Wang B, Lantin RS (1997) Factors and processes controlling methane emissions from rice fields. Nut Cycl Agroecosyst 49:111-117

Oenema O, Wrage N, Velthof GL, van Groenigen JW, Dolfing J, Kuikman PJ (2005) Trends in global nitrous oxide emissions from animal production systems. Nut Cycl Agroecosyst 72:51-65

Öhlinger R (1996) Biomass- P by fumigation-extraction technique. In: Kandeler E, Margesin R, Schinner F, Hlinger R (eds) Methods in soil biology. Springer, Berlin, pp 62-64

Pan GX, Li LQ, Wu L, Zhang XH (2004) Storage and sequestration potential of topsoil organic carbon in China's paddy soils. Global Chan Biol 10:79-92

RDA (Rural Development Administration) (1988) Methods of soil chemical analysis. National Institute of Agricultural Science and Technology, Suwon

RDA (Rural Development Administration, Korea) (1999) Fertilization standard of crop plants. National Institute of Agricultural Science and Technology, Suwon, p 148

Rodhe H (1990) A comparison of the contribution of various gases to the greenhouse effect. Science 284:1217-1219

Rolston DE (1986) Gas flux. In: Klute A (ed) Methods of soil analysis, part 1, 2nd edn. ASA and SSSA, Madison, pp 1103-1119 (Agron. Monogr. 9) 
Saito M, Miyata A, Nagai H, Yamada T (2005) Seasonal variation of carbon dioxide exchange in rice paddy field in Japan. Agric Forest Meteorol 135:93-109

SAS Institute (1995) System for windows release 6.11. SAS Institute, Cary

Sass RL, Fisher FM, Wang YB, Turner FT, Jund MF (1992) Methane emission from rice fields: the effect of floodwater management. Global Biogeochem Cycl 6:249-262

Shang QY, Yang XX, Gao C, Wu PP, Liu JJ, Xu Y, Shen QR, Zou JW, Guo SW (2010) Net annual global warming potential and greenhouse gas intensity in Chinese double rice-cropping systems: a 3-year field measurement in long-term fertilizer experiments. Global Chan Biol 17:2196-2210

Sharma SK, Singh YV, Tyagi Suruchi, Bhatia Arti (2016) Influence of rice varieties, nitrogen management and planting methods on methane emission and water productivity. Paddy Water Environ 14:325-333

Shiratori Y, Watanabe H, Furukawa Y, Tsuruta H, Inubushi K (2007) Effectiveness of a subsurface drainage system in poorly drained paddy fields on reduction of methane emissions. Soil Sci Plant Nut 53:387-400

Singh S, Singh JS, Kashyap AK (1999) Methane flux from irrigated rice fields in relation to crop growth and $\mathrm{N}$-fertilization. Soil Biol Biochem 31:1219-1228

Smith P, Lanigan G, Kutsch WL, Buchmann N, Eugster W, Aubinet M, Ceschia E, Béziat P, Yeluripati JB, Osborne B, Moors EJ, Brut A, Wattenbach M, Saunders M, Jones M (2010) Measurements necessary for assessing the net ecosystem carbon budget of croplands. Agric Ecosyst Environ 139:302-315

Solomon S, Qin D, Manning M, Chen Z, Marquis M (2007) Contribution of working group I to the fourth assessment report of the intergovernmental panel on climate change. Cambridge University Press, Cambridge
Takai Y (1961) Reduction and microbial metabolism in paddy soils (3). Nogyo Gijitsu Agric Technol 19:122-126

Vance ED, Brookes PC, Jenkinson DS (1987) An extraction method for measuring soil microbial biomass C. Soil Biol Biochem 19:703-707

Wassmann R, Papen H, Rennenberg H (1993) Methane emission from rice paddies and possible mitigation strategies. Chemosphere 26:201-217

Win KT, Nonaka R, Win AT, Sasada Y, Toyota K, Motobayashi T (2015) Effects of water saving irrigation and rice variety on greenhouse gas emissions and water use efficiency in a paddy field fertilized with anaerobically digested pig slurry. Paddy Water Environ 13:51-60

Xiao Y, Xie G, Lu G, Ding X, Lu Y (2005) The value of gas exchange as a service by rice paddies in suburban Shanghai, PR China. Agric Ecosyst Environ 109:273-283

Xiong ZQ, Xing GX, Zhu ZL (2007) Nitrous oxide and methane emissions as affected by water, soil and nitrogen. Pedosphere $17: 146-155$

Yagi K, Tsuruta H, Kanda K, Minami K (1996) Effect of water management on methane emission from a Japanese rice paddy field: automated methane monitoring. Global Biogeochem Cycl 10:255-267

Yan X, Du L, Shi S, Xing G (2000) Nitrous oxide emission from wetland rice soil as affected by the application of controlled availability fertilizers and mid-season aeration. Biol Fert Soils 32:60-66

Zheng XH, Xie BH, Liu C, Zhou Z, Yao ZS, Wang Y, Yang L, Zhu J, Huang Y (2008) Quantifying net ecosystem carbon dioxide exchange of a short-plant cropland with intermittent chamber measurements. Global Biogeochem Cycl 22:GB3031 